\title{
Variability in yield parameters of onion genotypes in Bundelkhand region of Uttar Pradesh
}

\author{
R K Singh ${ }^{1}$, Mritunjay Rai $^{2}$, A C Mishra ${ }^{1} \&$ S V Dwivedi ${ }^{1}$ \\ ${ }^{1}$ Department of Vegetable Science, College of Horticulture, Banda University of Agriculture and \\ Technology, Banda-210 001 (UP) \\ ${ }^{2}$ Department of Vegetable Science, College of Horticulture and Forestry, Acharya Narendra Deva \\ University of Agriculture and Technology, Ayodhya-224 229, Uttar Pradesh (U.P)
}

*Email: rmritunjay602@gmail.com

Received 22 September 2021; Revised 21 November 2021; Accepted 28 November 2021

\begin{abstract}
Of the seventeen onion varieties evaluated for assessment of variability in mean performance, variances, heritability and genetic advance, (L-883 and Bhima Shweta) were most promising genotypes in respect of gross and marketable bulb yield, minimum number of bolters, rotten and multi-centred bulbs, bulb weight, equatorial bulb diameter, total soluble solids, number of leaves per plant and earliness in maturity. High values of genetic and phenotypic for gross and marketable bulb yield, average bulb weight, days to $70 \%$ neck fall and plant height indicated more opportunity of selection for these traits. High genetic advance as percentage of mean coupled with high heritability was observed for gross and marketable bulb yield and average bulb weight. Therefore, significant improvement could be expected through selection for these traits.
\end{abstract}

Keywords: onion, genetic variability, Bundelkhand, genetic variance, heritability

\section{Introduction}

Onion is an important crop of India grown in 12.85 lakh hectare with a production of 232.62 lakh metric tonnes. (Anon., 2018). The area and production in seven districts of Bundelkhand region of U.P. (Chitrakoot,
Banda, Hamirpur, Mahoba, Jalaun, Jhansi and Lalitpur) is 1120 hectares and 20280 metric tonnes, respectively. The national as well as regional productivity of onion is very low (18.1 tonne ha ${ }^{-1}$ ). Poor productivity of this crop may be due to including lack of region specific, high yielding varieties, improved production 
packages and quality seeds. In recent years, large number of varieties and hybrids have been developed by National Institutes like Directorate of Onion \& Garlic Research, IIHR, NHRDF IARI and State Agricultural Universities like MPKV for cultivation in a wide range of agro-climatic conditions of the country in different seasons. However, a few or no variety has been developed specifically for Bundelkhand region. In such circumstances, evaluation of available varieties/genotypes is necessary for identification of suitable ones in relation to yield and variability parameters for direct adoption in farmers' field or utilization as parents in further breeding programmes. Like Andhra Pradesh, Telangana, Karnataka, Maharashtra and major part of Madhya Pradesh, Bundelkhand region of Uttar Pradesh is suitable for onion cultivation during Rabi, late Kharif and Kharif seasons. In the view of yield, remuneration and availability of irrigation water, late Kharif onion is more important crop in this region. Therefore, evaluation of genotypes is utmost important for promoting kharif onion cultivation in this region.

\section{Materials and methods}

The field experiments for present investigation were conducted at the Vegetable Research Station of Banda University of Agriculture and Technology, Banda (latitude between $24^{\circ}$ $53^{\prime}$ and $25^{\circ} 55^{\prime} \mathrm{N}$ and longitude $80^{\circ} 07^{\prime}$ and $81^{\circ} 34^{\prime} \mathrm{E}$ ) during kharif (August to December) of 2018 and 2019. The experiments were laid out in randomized block design with three replications. The treatments included seventeen varieties released from DOGR, Pune, NHRDF, Nashik, IIHR, Bengaluru, IARI, New Delhi and MPKV, Rahuri. Seedlings were raised in nursery during last week of June to first week of July and transplanted during second and third week of August. The seedlings of 45 days old were transplanted at $15 \times 10 \mathrm{~cm}$ spacing. Data were recorded for plant height $(\mathrm{cm})$, number of leaves per plant, neck thickness (cm), equatorial bulb diameter $(\mathrm{cm})$, polar bulb diameter $(\mathrm{cm})$, equatorial to polar bulb diameter ratio, 20 bulbs weight $(\mathrm{kg})$, average bulb weight $(\mathrm{g})$, multicentred bulbs $(\%)$, bolter bulbs $(\%)$, rotten bulbs (\%), total soluble solids (0 Brix), days to $70 \%$ neck fall (days after transplanting), Gross bulb yield ( $\mathrm{q} \mathrm{ha}^{-1}$ ) and marketable bulb yield $\left(\mathrm{q} \mathrm{ha} \mathrm{a}^{-1}\right)$. The data were analysed statistically for components of variance and genetic variability parameters viz., standard error of mean, critical difference, variance \& coefficients of variation at genotypic and phenotypic levels (Burton, 1952). The heritability in broad sense (\%), response to selection and genetic advance as percentage of mean (\%) were computed as per Johnson et al. (1955).

\section{Results and discussion}

Variability in mean performance of genotypes

All the genotypes included in this study showed significant variability for different traits except plant height and bulb neck thickness (Table 1). Significantly higher and at par values of gross and marketable bulb yield was realized in L-883 (244.17 q ha-1 \& $220.0 \mathrm{q} \mathrm{ha}^{-1}$, respectively) and Bhima Shweta (234.17 q ha- $\& 226.67 \mathrm{q} \mathrm{ha}^{-1}$, respectively). Minimum gross and marketable bulb yield was realized in Arka Kalyan (157.50 q ha-1 \& $149.17 \mathrm{q} \mathrm{ha}^{-1}$, respectively). A range of $85.2 \mathrm{q} \mathrm{ha}^{-1}$ to $324.2 \mathrm{q} \mathrm{ha}^{-1}$ bulb yield was reported in onion genotypes by Hosamani et al. (2010) under Karnataka conditions.

The genotypes B-780 and L-883 exhibited no bolter bulbs and rotten bulbs whereas, Bhima Super, Bhima Shweta and Agri found Dark Red registered minimum value up to $(0.44 \%)$ for these undesirable traits (Table 2). Another undesirable trait in onion is multi-centred bulbs which lead to deformation in shape and poor storability of bulbs. Minimum number 
Table 1. Analysis of variance for different traits in onion

\begin{tabular}{|c|c|c|c|c|}
\hline \multirow[t]{3}{*}{ Trait } & \multirow{2}{*}{$\begin{array}{l}\text { Source of } \\
\text { variation }\end{array}$} & \multicolumn{3}{|c|}{ Mean Sum of Squares } \\
\hline & & Replication & Treatments & Error \\
\hline & $\mathrm{DF}$ & 2 & 16 & 32 \\
\hline Plant height $(\mathrm{cm})$ & & 5.08 & 24.59 & 13.85 \\
\hline Number of leaves per plant & & 2.43 & $1.39^{* *}$ & 0.37 \\
\hline Bulb neck thickness $(\mathrm{cm})$ & & 0.01 & 0.02 & 0.01 \\
\hline Equatorial bulb diameter $(\mathrm{cm})$ & & 0.02 & $0.09 * *$ & 0.01 \\
\hline Polar bulb diameter $(\mathrm{cm})$ & & 0.02 & $0.22^{* *}$ & 0.03 \\
\hline Equatorial to polar bulb diameter ratio & & 0.00 & $0.01^{* *}$ & 0.00 \\
\hline 20 bulb weight $(\mathrm{kg})$, & & 3.79 & $6.55^{* *}$ & 2.60 \\
\hline Average bulb weight (g) & & 1.77 & $135.66^{* *}$ & 8.29 \\
\hline Multi-centred bulbs (\%) & & 0.03 & $1.12^{* *}$ & 0.26 \\
\hline Bolter bulbs (\%) & & 0.31 & $0.35^{* *}$ & 0.07 \\
\hline Rotten bulbs (\%) & & 0.14 & $0.38^{* *}$ & 0.07 \\
\hline Total soluble solids ( $\left.{ }^{0} \mathrm{Brix}\right)$ & & 0.05 & $2.16^{* *}$ & 0.39 \\
\hline Days to $70 \%$ neck fall (DAT) & & 14.20 & $39.79^{* *}$ & 5.40 \\
\hline Gross bulb yield (q ha-1) & & 110.02 & $2380.73^{* *}$ & 31.37 \\
\hline Marketable bulb yield (q ha-1) & & 29.07 & $2303.78^{* *}$ & 35.59 \\
\hline
\end{tabular}

${ }^{* *}$ significant at $5 \%$

of multi-centred bulbs were recorded in L-883 (0.27\%) followed by B-780 (0.88\%) and Bhima Super $(0.97 \%)$ which were at par. The genotypes L-883 and Bhima Shweta showed significantly higher and at par values of average and 20 bulbs weight $(62.50 \mathrm{~g} \& 1.25 \mathrm{~kg}$ and $60.33 \mathrm{~g}$ $\& 1.21 \mathrm{~kg}$, respectively). The other genotypes with higher values of average and 20 bulbs weight were Bhima Super $(55.0 \mathrm{~g} \& 1.10 \mathrm{~kg}$, respectively), Agri found Dark Red (54.17 g \& $1.08 \mathrm{~kg}$, respectively), Bhima Raj (53.33 g \& $1.07 \mathrm{~kg}$, respectively), Bhima Shubhra and B-780 (50.0 g \& $1.00 \mathrm{~kg}$, respectively). A wide variability in bulb weight ranging from $26.67 \mathrm{~g}$ to $84.00 \mathrm{~g}$ has also been reported by Hosamani et al. (2010) across 21 genotypes of onion.

The equatorial and polar bulb diameter and their ratio are metric traits decisive for bulb shape and appearance which have prime importance in export quality onion. Generally, flat-round bulbs are desirable over the pearshaped ones in the view of higher compactness and storability in former ones. In this way, higher value of equatorial and lower of polar bulb diameter is required for desirable bulb shape. In view of desirable bulb shape, higher value for equatorial bulb diameter was recorded in L-883 $(5.56 \mathrm{~cm})$, Bhima Shweta (5.43 $\mathrm{cm})$, Bhima Super and ADR $(5.35 \mathrm{~cm})$. Lowest value of polar bulb diameter was recorded in N-53 $(3.73 \mathrm{~cm})$ followed by Arka Kalyan (3.99 $\mathrm{cm})$, Pusa Sona, Pusa Red $(4.03 \mathrm{~cm})$ and Phule Samarth $(4.07 \mathrm{~cm})$. The equatorial and polar bulb diameter indicates difference between these two types of bulb diameter. Higher value of this ratio indicates flat-round bulb shape, the value less than 1.0 indicates pyriform shape of bulbs and that equal to 1.0 or around indicates oval-round shape. In the light of such categorization, the genotypes viz., Bhima Dark Red (1.12), Bhima Shweta (1.15), Bhima 
Red (1.16), B-780 (1.17), Phule Suvarna \& L-883 (1.19), Bhima Super (1.21) and N-2-4-1 \& ADR (1.22) showed oval-round bulb shape whereas rest of the genotypes had flat-round bulb shape (Table 2).

Total soluble solids (TSS) signify nutritional quality of bulbs by the way of accumulation minerals and sugars in cytoplasm. Higher value of TSS was recorded in L-883, Bhima Raj (12.33 Brix), Bhima Shweta (12.27 Brix), Bhima Super (11.92 Brix), Bhima Dark Red, Phule Safed (11.77 Brix), Bhima Red (11.63 Brix) and Agrifound Dark Red (11.60 Brix).

The genotypes L-883, N-2-4-4 and B-780 registered earliness in maturity in terms of days to $70 \%$ neck fall (80-88 DAT). The foliage of onion is known for its photosynthetic efficiency. The foliaceous plants are supposed to give voluminous bulbs which were evident from synergic data on number of leaves per plant and gross/marketable bulb yield (Table 2). Maximum number of leaves per plant was counted in Bhima Shweta (8.67) followed by L-883 (8.33), Agri found Dark Red \& B-780 (8.00), Pusa Sona, Bhima Super \& Bhima Dark Red (7.67).

From the mean performance of genotypes, it is evident that L-883 and Bhima Shweta were most promising genotypes in respect of gross and marketable bulb yield, minimum number of bolters, rotten and multi-centred bulbs, bulb weight, equatorial bulb diameter, total soluble solids, number of leaves per plant and earliness in maturity. Other genotypes with one or more number of desirable traits were B-780, ADR, Bhima Super and Bhima Raj. These genotypes could be utilized in further onion improvement programmes in Bundelkhand.

\section{Genetic variance parameters}

The data on genetic variability parameters indicated that the value of genotypic variance for all the traits studied were higher in magnitude than that at phenotypic level proving remarkable environmental effects on expression of genes (Table 3). High values of genetic and phenotypic variances were noted for gross and marketable bulb yield (q ha-1) (783.12 \& 814.49 and $756.07 \& 791.65$, respectively), average bulb weight (g) (42.46 \& 50.74, respectively), days to $70 \%$ neck fall (DAT) (11.46 \& 16.87, respectively) and plant height $(\mathrm{cm})$ (3.58 \& 17.43, respectively). High coefficient of variations at genotypic and phenotypic levels were recorded for traits viz., 20 bulb weight (78.61 \& $135.57 \%$, respectively), rotten bulbs (96.16 \& 121.70\%, respectively), bolter bulbs (54.29 \& 70.87\%, respectively) and multi-centred bulbs (31.31 \& 43.25\%, respectively) whereas, moderate values were recorded for marketable bulb yield (15.12 \& $15.47 \%$, respectively), gross bulb yield (14.83 \& $15.12 \%$, respectively) and average bulb weight (13.44 \& $14.69 \%$, respectively). It indicated that because of presence of high value of variability parameters for bulb yield, bulb weight, rotten and multi-centred bulbs and days to $70 \%$ neck fall stage, these traits could have improved through direct selection. There were narrow difference between genotypic and phenotypic variances for most of these traits, (indicating presence of major portion of variability in population for these traits were due to genetic effect and selection would be more effective). High GCG and PCV for bulb yield and bulb weight have also been reported by Fatema (2001); Mohanty (2001); Haydar et al. (2007); Hosamani et al. (2010); Singh et al. (2010); and Singh et al. (2011) in onion.

Effectiveness of a particular breeding procedure for different traits is mainly influenced by heritability which is useful in determining the expression of phenotype related to the genotypic contribution of the trait. Johnson et al. (1955) stated that heritability values 


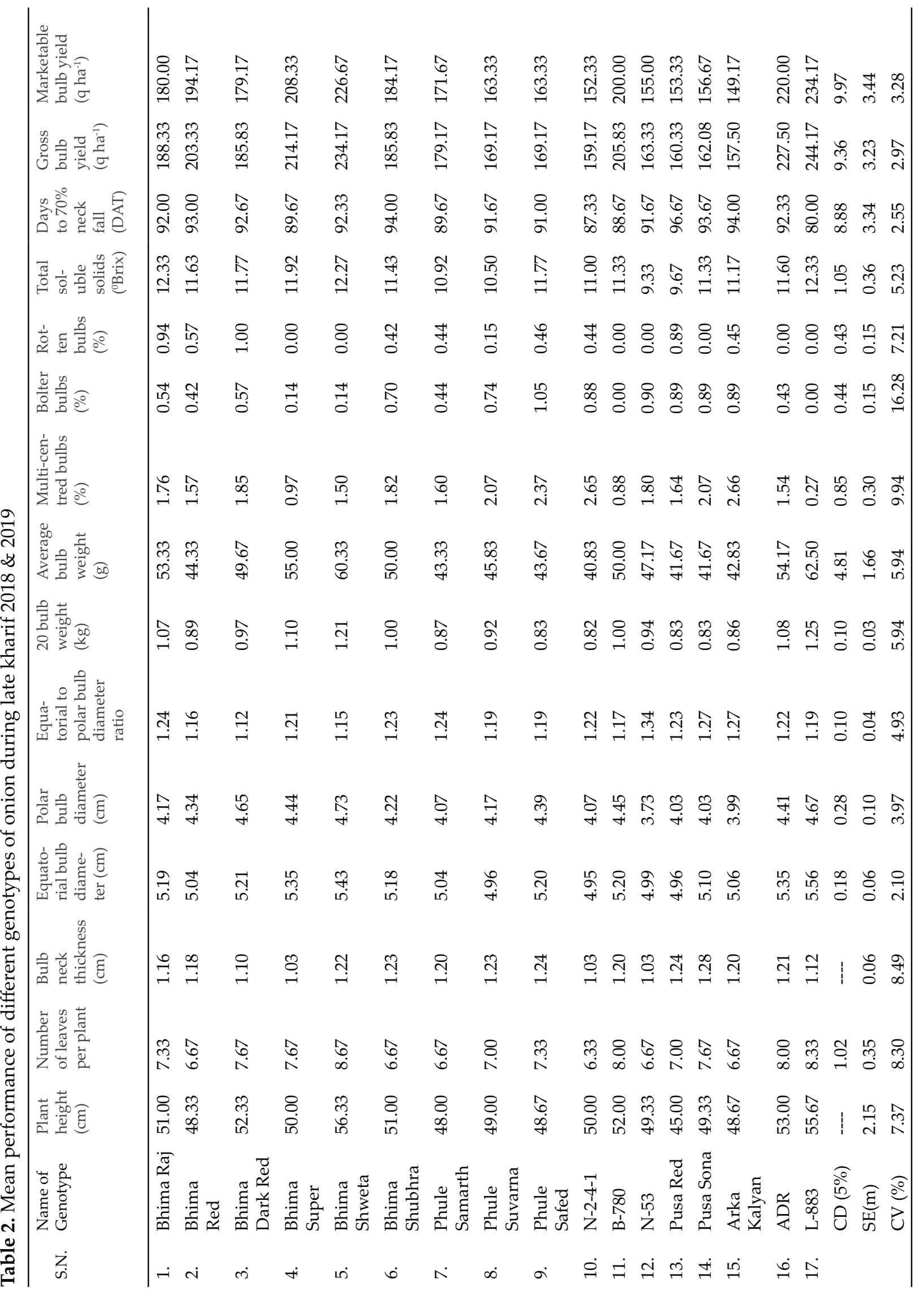




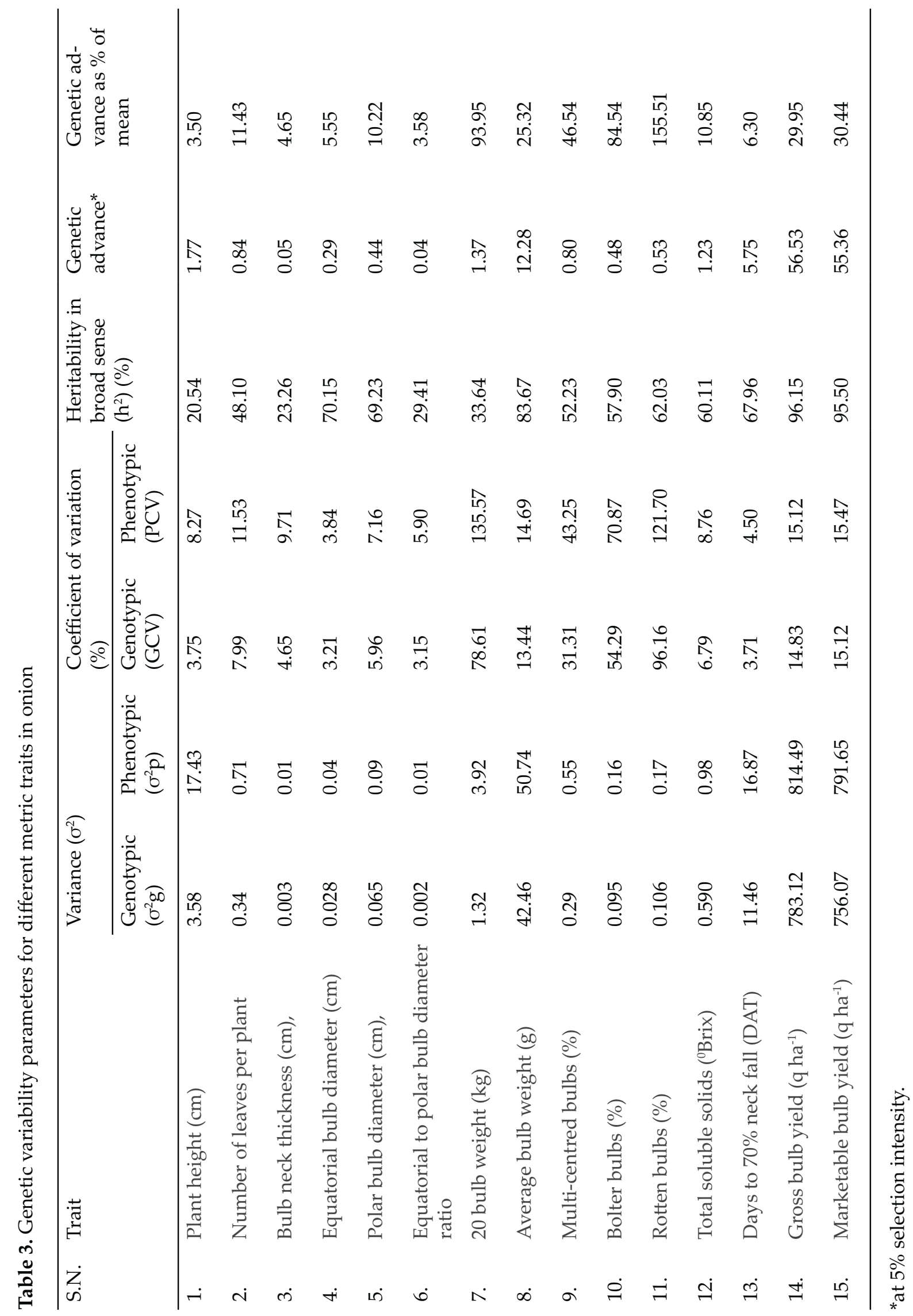


together with the genetic advance aided in predicting the expected progress through selection. High heritability in broad sense was realized for gross and marketable bulb yield (96.15\% \& 95.50\%, respectively) and average bulb weight (83.67\%). Fatema (2001); Mohanty (2001); Haydar et al. (2007) and Hosamani et al. (2010) have also noted high heritability for bulb yield and average bulb weight in onion. High heritability for different traits indicated that large proportion of phenotypic variance was attributed to genotypic variance and therefore, reliable selection could be made for these traits on the basis of phenotypic expression. High value for genetic advance as percentage mean (genetic gain) was noted for rotten bulbs (155.51\%), 20 bulbs weight (93.95\%), bolter bulbs (84.54\%), multi-centred bulbs (46.54\%), marketablebulb yield (30.44\%), gross bulb yield (29.95\%) and average bulb weight (25.32\%).

High heritability estimates coupled with high genetic advance indicates that traits were governed mainly due to additive genetic effect and therefore selection might be effective for those traits. Genetic advance (GA) is an improvement over the base population that could potentially be made from selection for a characteristic. It is a function of the heritability of the traits, the amount of phenotypic variation and the selection differential (the average phenotypic value of the selected individuals expressed as deviation from population mean) that breeder uses (Johnson et al. 1995). High genetic advance as percentage of mean coupled with high heritability was experienced for gross and marketable bulb yield (29.95 \& 30.44\%) and average bulb weight $(25.32 \%)$. Higher values of genetic advance and heritability estimates were obtained due to additive gene effect (Panse, 1957). The present results are in accordance with the reports of Patil et al. (1986); Sidhu et al. (1986); Mohanty (2001) and Haydar et al. (2007).
It is concluded that the variety L-883 was the most promising genotype in respect of gross and marketable bulb yield, minimum number of bolters, bulb weight, equatorial bulb diameter, TSS and earliness in maturity.

\section{Acknowledgements}

The authors are thankful to Vice Chancellor, Banda University of Agriculture and Technology, Uttar Pradesh, for providing financial support to carry out the experiments.

\section{References}

Anonymous 2018 Horticulture at a Glance-2018 Horticulture Statistics Division, Department of Agriculture \& Cooperation, Govt. of India.

Burton G W 1952 Quantitative inheritance in grasses. Proc. $6^{\text {th }}$ Int. Grass land Cong. 1: 277-283.

Fatema U J 2001 Variability and inter-relationship of yield and yield components of onion. M.Sc. Thesis. Department of Botany. Rajshahi University, Bangladesh.

Haydar A Sharker N Ahmed M B Hannan M M Razvy M A Hossain M Hoque A \& Karim R 2007 Genetic variability and inter-relationship in onion (Allium cepa L.). Middle-East J. Sci. Res. 2 (3-4): 132-134.

Hosamani R M Patil B C \& Ajjappalavara P S 2010 Genetic variability and character association studies in onion (Allium cepa L.). Karnataka J. Agric. Sci. 23 (2): 302-305.

Johnson H W Robinson H F \& Comstock RE 1955 Estimates of genetic and environmental variability in soybean. Agron. J. 47: 314-318.

Mohanty B K 2001 Genetic variability, interrelationship and path analysis in onion. J. Trop. Agric. 39: 17-20.

Panse V G 1957 Genetics of quantitative characters in relation to plant breeding. Indian J. Genetics. 17: 318-328.

Patil J D Desele G Y \& Kale P N 1986 Genetic variability studies in onion. J. Maharashtra Agric. Uni. 11: 281-283. 
Sidhu A S Singh S \& Thakur M R 1986 Variability and correlation studies in onion. Indian J. Horticulture. 43: 260-264.

Singh R K Dubey B K Bhonde S R \& Gupta R P 2010 Estimates of genetic variability, heritability and correlation in red onion (Allium cepa L.) advance lines. Indian J. Agric. Science 80 (2): 160-163.

Singh R K Bhonde S R \& Gupta R P 2011 Studies on genetic variability in late Kharif (Ragada) onion (A. cepe L). J. App. Horticulture. 13: 79-82. 